\title{
Tingkat Kemudahan dan Manfaat pada Penggunaan Layanan Go-Pay bagi Minat Pengguna di Indonesia
}

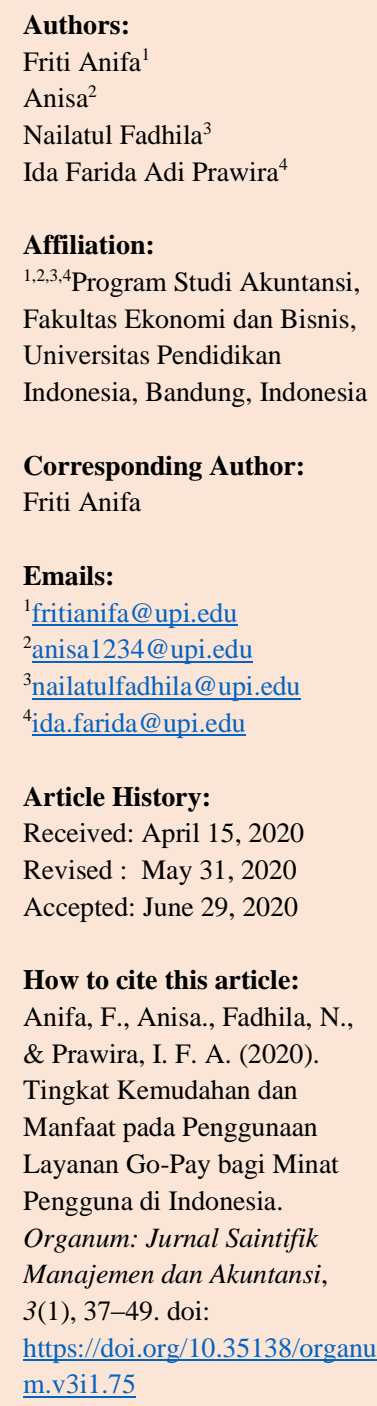

How to cite this article: Anifa, F., Anisa., Fadhila, N., \& Prawira, I. F. A. (2020). Tingkat Kemudahan dan Manfaat pada Penggunaan Layanan Go-Pay bagi Minat Pengguna di Indonesia. Organum: Jurnal Saintifik Manajemen dan Akuntansi, 3(1), 37-49. doi: https://doi.org/10.35138/organu m.v3i1.75

Journal Homepage: ejournal.winayamukti.ac.id/ind ex.php/Organum

\section{Copyright:} (C) 2020. Published by Organum: Jurnal Saintifik Manajemen dan Akuntansi. Faculty of Economics and Business. Winaya Mukti University.

\begin{abstract}
The development of financial technology in Indonesia is followed by innovation, namely, the presence of E-Money. Go-Pay is a form of E-Money in Indonesia which is a mobile payment service found on the Go-Jek platform. This study provided a summary graphic representation of the theory-consistent evidence about the causes and effects of user interests of Go-Pay system in Indonesia. Some of the conveniences and benefits obtained from services such as top-up, payments, and fund transfers. The method used in this study is the type of library research. Data collection techniques used are qualitative data collection using existing data sources, that is, using data reduction to then concludes with logic, aesthetics, and ethics. Based on research that had been done, it could be concluded that the conveniences and benefits felt by consumers significantly affected their demand for using Go-Pay services. The implications of this research for science are as consideration for Go-Jek companies to increase the conveniences and benefits in Go-Pay payments, which implies increasing GoJek demand.
\end{abstract}

Keywords: Fintech; Go-Pay; user interest; E-Money.

Abstrak. Perkembangan financial technology di Indonesia diikuti dengan inovasi baru yaitu dengan hadirnya E-Money. Go-Pay merupakan wujud E-Money di Indonesia yang merupakan layanan mobile payment yang terdapat pada platform Go-Jek. Penelitian ini memberikan ringkasan representasi grafik dari bukti teorikonsisten tentang penyebabnya dan pengaruh minat pengguna terhadap sistem Go-Pay di Indonesia. Beberapa kemudahan dan manfaat yang didapatkan dari layanannya seperti top-up, pembayaran, dan transfer dana. Metode yang digunakan dalam penelitian ini adalah jenis penelitian kepustakaan (library research). Teknik pengumpulan data yang digunakan adalah pengumpulan data kualitatif dengan menggunakan sumber data yang sudah ada, yakni menggunakan reduksi data kemudian melakukan penarikan kesimpulan dengan logika, estetika, dan etika. Berdasarkan penelitian yang telah dilakukan, dapat disimpulkan bahwa kemudahan dan kebermanfaatan yang dirasakan konsumen sangat memengaruhi permintaan mereka dalam menggunakan layanan Go-Pay. Implikasi penelitian ini bagi ilmu pengetahuan yaitu sebagai bahan pertimbangan bagi perusahaan Go-Jek untuk meningkatkan kemudahan dan kebermanfaatan dalam pembayaran Go-Pay yang berimplikasi pada peningkatan permintaan Go-Jek.

Kata kunci: Fintech; Go-Pay; minat pengguna; uang-el.

\section{Pendahuluan}

$\mathrm{P}$ ada saat ini, dompet digital masih asing bagi pengguna uang tunai, oleh sebab itu Go-Jek merupakan perusahaan yang menawarkan dompet digital, Go-Pay membuat calon 
pengguna menyadari keberadaannya serta segera menarik perhatian calon pengguna. Hal ini dilakukan dengan memberi secara gratis saldo atau diskon besar saat membayar menggunakan Go-Pay. Kesan awal yang menarik dari diskon dan kenyamanan yang ditawarkan membuat pengguna Go-Pay semakin tertarik dan terus menggunakan Go-Pay. Bahkan ketika tiga dari enam informan mengalami masalah dengan layanan Go-Jek dan GoPay mereka, tanggapan dari Customer Service (CS) Go-Jek yang cepat memberikan rasa aman dan kepastian untuk uang mereka itu masih terjebak dalam aplikasi (Kesumastuti, 2020).

Keberadaan Fintech menciptakan efisiensi dan transaksi praktis, khususnya di bidang ekonomi di Indonesia maupun di berbagai negara (Danuarta \& Darma, 2019). Bank Indonesia (2020) menjelaskan bahwa Fintech timbul bersamaan dengan perubahan gaya hidup masyarakat yang sekarang didominasi oleh pengguna teknologi informasi sebagai tuntutan hidup yang serba kilat. Dengan Fintech, kasus dalam transaksi jual-beli serta pembayaran seperti tidak sempat dalam mencari barang ke tempattempat perbelanjaan, ke bank atau Anjungan Tunai Mandiri (ATM) untuk mengirim dana, keengganan mendatangi suatu tempat yang disebabkan karena pelayanan yang kurang memuaskan dapat diminimalisir. Dengan kata lain, Fintech dapat membantu transaksi jual beli serta sistem pembayaran menjadi lebih efisien, ekonomis, dan efektif.

Ojek yang dipesan secara online dan banyak digunakan pada smartphone saat ini, salah satu yang dikenal adalah Go-Jek. Moda transportasi antar jemput yang memakai media panggil gadget atau smartphone secara online ini berdiri pada bulan Juni 2010 yang didirikan oleh Nadiem Makarim sebagai CEO, Brian $\mathrm{Cu}$, dan Michaelangelo Maron. Saat ini perhatian terhadap kepuasan ataupun ketidakpuasan pelanggan telah semakin meningkat disebabkan karena pada dasarnya tujuan suatu perusahaan yaitu untuk menghasilkan rasa puas pelanggan. Konsumen yang puas bisa menjadi suatu sumber pemasaran yang efektif untuk perusahaan, salah satunya terdapat rekomendasi layanan Teknologi Informasi (TI) di aplikasi Go-Jek kepada pihak lain sehingga menaikkan jumlah pelanggan Go-Jek (Wulandari et al., 2016). Go-Pay adalah suatu produk Fintech yang dihadirkan oleh Go-Jek untuk memudahkan sistem keuangan perusahaan (Liu et al., 2015).

Berdasarkan data Q2 2019 dari App Annie, salah satu dari lima besar aplikasi $e$-wallet dengan pengguna aktif dalam bulanan masih diduduki dengan pemain Go-Pay, Ovo, Dana, LinkAja, serta Jenius. Jumlah aplikasi $e$-wallet yang diunduh dan berhasil menduduki urutan lima teratas yaitu Go-Pay di urutan pertama, Ovo di urutan kedua, Dana di urutan ketiga, LinkAja di urutan keempat, dan iSaku di urutan kelima. Walaupun Go-Pay telah populer, metode pembayaran tunai tampaknya masih mendominasi di Indonesia. Survei dari The G4S menyatakan bahwa hasil survei menunjukkan 50-55\% transaksi keuangan Indonesia masih didominasi oleh pertukaran uang tunai 18 negara masih menggunakan metode yang sama dari 24 negara yang telah disurvei seperti negara Thailand dan India, mereka masih banyak menggunakan cash on delivery dan sistem tunai. Pada tahun 2012 sampai tahun 2016 peredaran uang yang tumbuh sebesar 53,1\% menjadi Rp528,53. Hal ini berdampak penarikan ATM dalam periode meningkat sebesar $65,5 \%$ menjadi Rp2.343 triliun (Vivin, 2019).

Fenomena ini terjadi karena ada kepercayaan pada masyarakat yang menggunakan uang tunai, dapat digunakan kapan pun serta di mana pun, rahasia, tidak bisa diretas, dan tidak tergantung pada kecepatan internet. Inilah alasan mengapa orang masih enggan menggunakan Go-Pay. Selain itu, ada persepsi negatif orang tentang risiko 
menggunakan Go-Pay, misalnya pengungkapan informasi login pengguna kepada pihak ketiga dan akun Go-Pay diretas oleh peretas. Saat ini, ada kasus di mana pengguna Go-Pay mengalami masalah dalam menggunakan Go-Pay tersebut seperti pengguna Go-Pay yang memakai layanan Go-Jek termasuk GoFood dan Go-Ride tidak dapat menggunakan pembayaran dengan GoPay. Selain masalah transaksi pembayaran, Go-Pay juga memiliki masalah dalam mengisi saldo Go-Pay. Sebelumnya, banyak netizen mengeluh bahwa saldo Go-Pay mereka bahkan tidak bertambah setelah isi ulang. Keluhan ini berasal dari pengguna yang melakukan top-up melalui berbagai bank. Pengguna yang menggunakan metode alternatif seperti top-up melalui pengemudi dan juga Alfamart mengeluh bahwa saldo mereka belum meningkat. Ini akan memengaruhi persepsi dan niat orang untuk menggunakan Go-Pay yang akan dapat memengaruhi pertumbuhan Go-Pay dan ekonomi Indonesia di masa depan (Danuarta \& Darma, 2019).

\section{Kajian Literatur}

\section{Financial Technology (Fintech)}

Fintech merupakan singkatan dari Financial Technology yang menggambarkan perusahaan maupun anak perusahaan yang menggabungkan layanan keuangan dan teknologi. Setiap perusahaan bersikeras untuk dikategorikan sebagai Fintech yang menawarkan produk berbasis internet serta aplikasi yang dipasang di gadget atau smartphone. Umumnya, bisnis modern ini diperuntukkan untuk menarik perhatian minat konsumen terhadap produk, kemudahan penggunaan layanan, efisiensi, serta transparansi dibandingkan dengan bisnis konvensional. Fintech tidak mungkin dikategorikan berdasarkan penggunaannya pada peraturan Pemerintah atau dokumen hukum. Perusahaan Fintech mematuhi jenis kewajiban hukum tertentu dan aturan yang berbeda karena jenis bisnis mereka. Perbedaan dalam bisnisnya adalah bahwa produk dan layanannya menawarkan banyak hal (Susilo et al., 2019).

Bank Indonesia (2020) menjelaskan bahwa Fintech adalah hasil penggabungan jasa keuangan serta teknologi dan akhirnya mengganti model bisnis konvensional menjadi moderat, yang pada awalnya pembayaran harus bertatap-muka serta membawa uang kas, sekarang bisa bertransaksi jarak jauh dengan melakukan pembayaran dalam hitungan detik saja.

\section{E-Money}

E-Money atau uang digital adalah wujud lain mata uang yang dikenal selama ini. Meskipun perbedaan antara E-Money dengan uang konvensional sangat terlihat jelas, tidak terdapat perbedaan nilai tukar antara E-Money dengan uang konvensional. Perbedaan E-Money dengan uang konvensional yaitu fleksibilitas serta aksesbilitas E-Money yang tidak ada batasan. Hal ini karena basis dalam transaksi E-Money adalah menggunakan sistem yang tersambung secara online serta orang yang bertransaksi tidak harus bertemu. Perkembangan E-Money berkembang mulai tahun 1960. Saat itu perusahaan komputer raksasa International Business Machine Corporation (IBM) bekolaborasi dengan American Airlines menghasilkan suatu sistem yang disebut Semi-Automatic Busines Research Environment (SABRE) dan memungkinkan dipasangnya terminal yang terhubung dengan jaringan telepon di kantor-kantor American Airlines yang menjadikan perusahaan dapat mengecek secara langsung jadwal keberangkatan, ketersediaan kursi, serta membuat pesanan secara digital dan kemudian dibayarkan dengan sistem kredit. Tahun 1970-an bank di Amerika serta Eropa menggunakan mainframe komputer untuk mendeteksi transaksi antar cabang serta bank lain, sistem ini pun teruji sukses melewati batasan internasional pertukaran 
kurs yang dibutuhkan (Aritonang \& Arisman, 2017).

\section{Go-Pay}

Go-Pay adalah suatu produk Fintech yang diperkenalkan oleh Go-Jek dalam mempermudah sistem keuangan di perusahaan. Faktor internal seperti heterogenitas perusahaan serta tingkat persaingan dan faktor eksternal seperti peraturan pemerintah serta standar teknologi ikut dalam pembentukan inovasi pembayaran dari metode konvensional menjadi mobile payment. Go-Pay merupakan layanan E-Money dan terdapat di aplikasi Go-Jek Indonesia. Go-Pay bisa digunakan dalam pembayaran semua layanan Go-Jek (Go-Ride, Go-Car, GoSend, dll) sampai transaksi non tunai di rekan usaha offline serta online (Liu et al., 2015).

Go-Pay merupakan uang elektronik yang dikeluarkan PT Dompet Anak Bangsa (DAB) dan terdaftar serta dipantau oleh Bank Indonesia. Go-Pay mempunyai fungsi yang sama dengan uang tunai serta bisa dipakai sebagai uang tunai instrumen pembayaran yang sah, memiliki nilai yang sama dengan nilai tunai yang disetor saat pertama kali pada akun Go-Pay. Akun Go-Pay merupakan akun untuk pengguna Go-Pay saat pendaftaran. Akun ini dibuat berdasarkan informasi yang diberikan saat pendaftaran. PT DAB berdiri dan beroperasi secara hukum di bawah hukum Republik Indonesia yang berkedudukan di DKI Jakarta dan menyediakan fasilitas pembayaran transaksi antara konsumen dengan pelaku bisnis (Ferdiana \& Darma, 2019).

Go-Pay memiliki beberapa layanan, yaitu top-up, pembayaran, dan transfer dana. Top-up merupakan layanan untuk mengisi saldo akun Go-Pay yang bisa diisi melalui driver Go-Jek, transfer dengan bank tertentu di Indonesia ataupun melalui lembaga dan platform lain yang bisa ditentukan oleh PT DAB. Saldo Go-Pay akan secara otomatis berkurang dengan jumlah yang sama saat pembayaran tagihan transaksi. Sedangkan transfer dana merupakan layanan yang ada di GoPay untuk mentransfer dana ke akun GoPay lainnya dan secara otomatis mengurangi saldo dalam Go-Pay pentransfer dengan kenaikan saldo akun Go-Pay pihak lain dalam jumlah yang sama (Aritonang \& Arisman, 2018).

\section{Metode Penelitian}

Dalam artikel ini, peneliti menggunakan tipe penelitian kepustakaan (library research), yaitu penelitian dilakukan hanya bersumber dari karya tertulis, baik hasil penelitian yang telah dipublikasikan maupun yang belum. Penelitian ini menggunakan pengumpulan data kualitatif dengan menggunakan datadata yang telah ada, seperti memakai reduksi data lalu menarik kesimpulan dengan memakai logika, estetika, serta etika. Sumber pustaka yang peneliti ambil bersumber dari jurnal ilmiah, buku, dan web page.

Penelitian ini dibuat dengan mengkaji perolehan data sekunder yang bersumber dari pihak lain. Pada studi ini, data sekundernya adalah hasil penelitian pihak lain yang dapat mendukung penulis dalam melengkapi dan menginterpretasi data yang diperoleh dari sumber data primer. Penulis mengambil sumber data sekunder yang berupa tulisan-tulisan dan mencoba mengulas beberapa pemikiran tentang tingkat kemudahan dan manfaat penggunaan layanan Go-Pay bagi minat pengguna di Indonesia serta beberapa literatur yang terkait dengan penelitian yang dilakukan.

Penelusuran data dimulai dengan penulisan keyword "Go-Pay" di Google dan ditemukan 17.300.000 artikel yang relevan. Selanjutnya artikel tersebut dipersempit memakai keyword jurnal internasional sehingga menghasilkan 82.000 artikel. Setelah itu, kami membatasi artikel yang kami cari dengan menelusuri tahun terbit jurnal antara tahun 1985 sampai tahun 2020 sehingga didapatkan 31.000 artikel terkait. Setelah 
itu, didapatkan beberapa artikel dan diuji pada laman Beallist dan laman Science and Technology Index (SINTA). Kemudian didapatkan artikel jurnal dengan total 17 artikel jurnal internasional dan 13 jurnal lokal bereputasi yang cocok dan sesuai dengan tema yang dikaji. Dari jurnal yang didapatkan tersebut, terdapat beberapa jurnal internasional seperti Elsevier, Scientific Research, Atlantis Press, IJMMU, dan IJRR.

\section{Hasil dan Pembahasan}

Berdasarkan penelitian yang telah kami lakukan ada beberapa pengaruh kemudahan dan manfaat dalam menggunakan layanan Go-Pay terhadap minat pengguna. Hal berikut menunjukkan bahwa dompet digital telah digunakan oleh masyarakat Indonesia dan dianggap sebagai alternatif dalam metode pembayaran. Dengan memahami tahapan minat dalam penggunaan dompet digital, terutama pada Go-Pay dari aplikasi GoJek, dapat dilihat dari proses awalnya sehingga Go-Pay menjadi pilihan utama pengguna dompet digital. Pengalaman baik dan buruk menjadi pertimbangan dalam fase evaluasi, selanjutnya dalam menentukan apakah pengguna ingin menggunakan Go-Pay menjadi metode pembayaran mereka atau tidak. Setelah informan melalui berbagai pertimbangan,
Go-Pay dianggap sebagai dompet digital terbaik dan dimiliki menjadi pilihan dompet digital favorit yang memberikan lebih banyak manfaat dan sedikit kekurangan daripada dompet digital lainnya. Kegunaan yang dirasakan merupakan suatu kondisi di mana teknologi dapat meningkatkan kinerja individu. Karena Go-Jek dan Go-Pay telah memenuhi kegunaan dan kemudahan yang dirasakan, itu menjadi dasar bagi pengguna untuk mengadopsi Go-Pay. Manfaat dan kemudahan penggunaan yang dirasakan dapat menjawab pertanyaan penelitian tentang tahapan dalam membentuk minat adopsi. Semakin mudah teknologinya dan semakin bermanfaat teknologinya, semakin cepat pula teknologi itu diadopsi (Kesumastuti, 2020). Hal tersebut didukung dalam penelitian Joan dan Sitinjak (2019) yang menyajikan terkait persepsi kebermanfaatan mempunyai pengaruh langsung, positif, serta signifikan pada minat penggunaan. Perubahan pada tingkat persepsi kebermanfaatan akan memengaruhi tingkat minat penggunaan Go-Pay.

Berdasarkan survei yang dilakukan oleh Eka (2019) yang dirangkum dalam laporan Fintech 2019 dan diikuti oleh 651 orang responden, didapatkan grafik pada gambar berikut ini. 


\section{Gambar 1. Top 10 Penggunaan Dompet Digital di Indonesia}

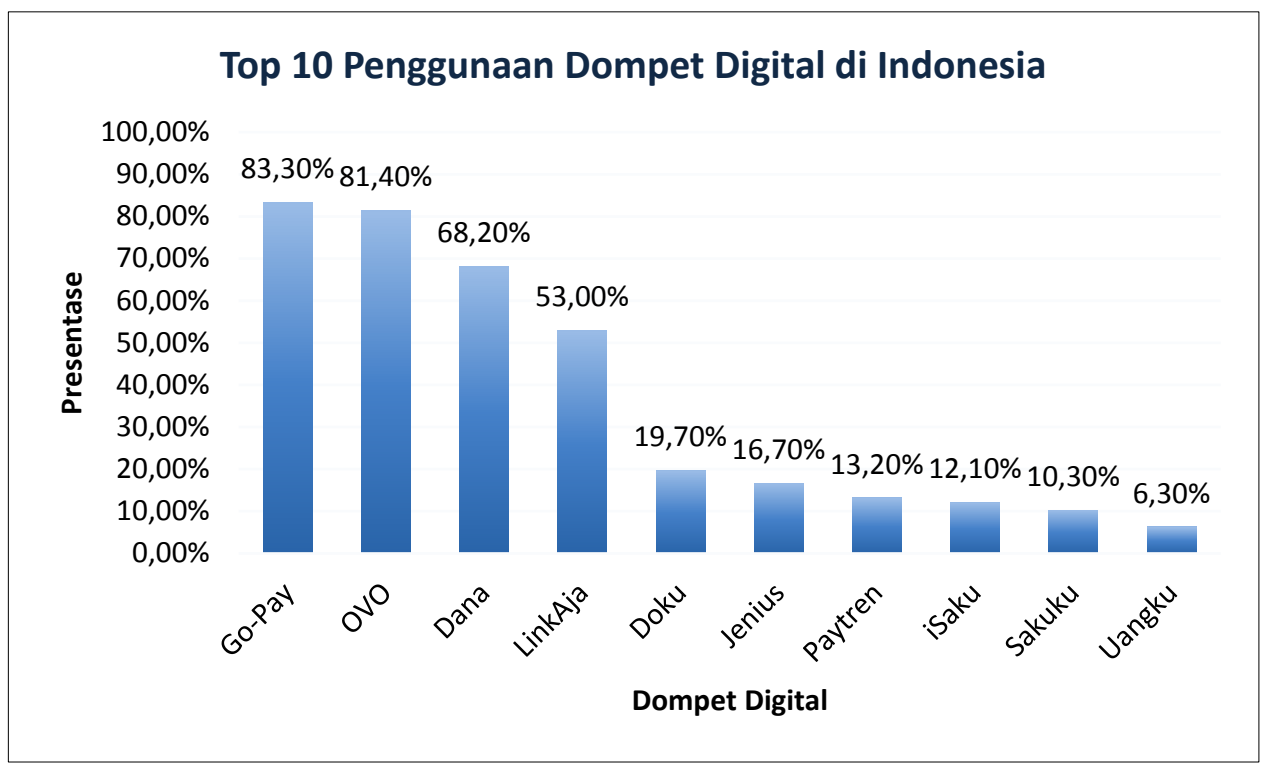

Sumber: Dailysocial Fintech Report (Eka, 2019)

Grafik pada Gambar 1 menunjukkan bahwa ada 10 pilihan dompet digital yang ada di Indonesia seperti Go-Pay, OVO, Dana, LinkAja, Doku, Jenius, Paytren,
iSaku, Sakuku, dan Uangku. Go-Pay menjadi pilihan dompet digital yang paling banyak digunakan oleh masyarakat Indonesia.

Gambar 2. Alasan Pengunaan Dompet Digital di Indonesia Tahun 2019

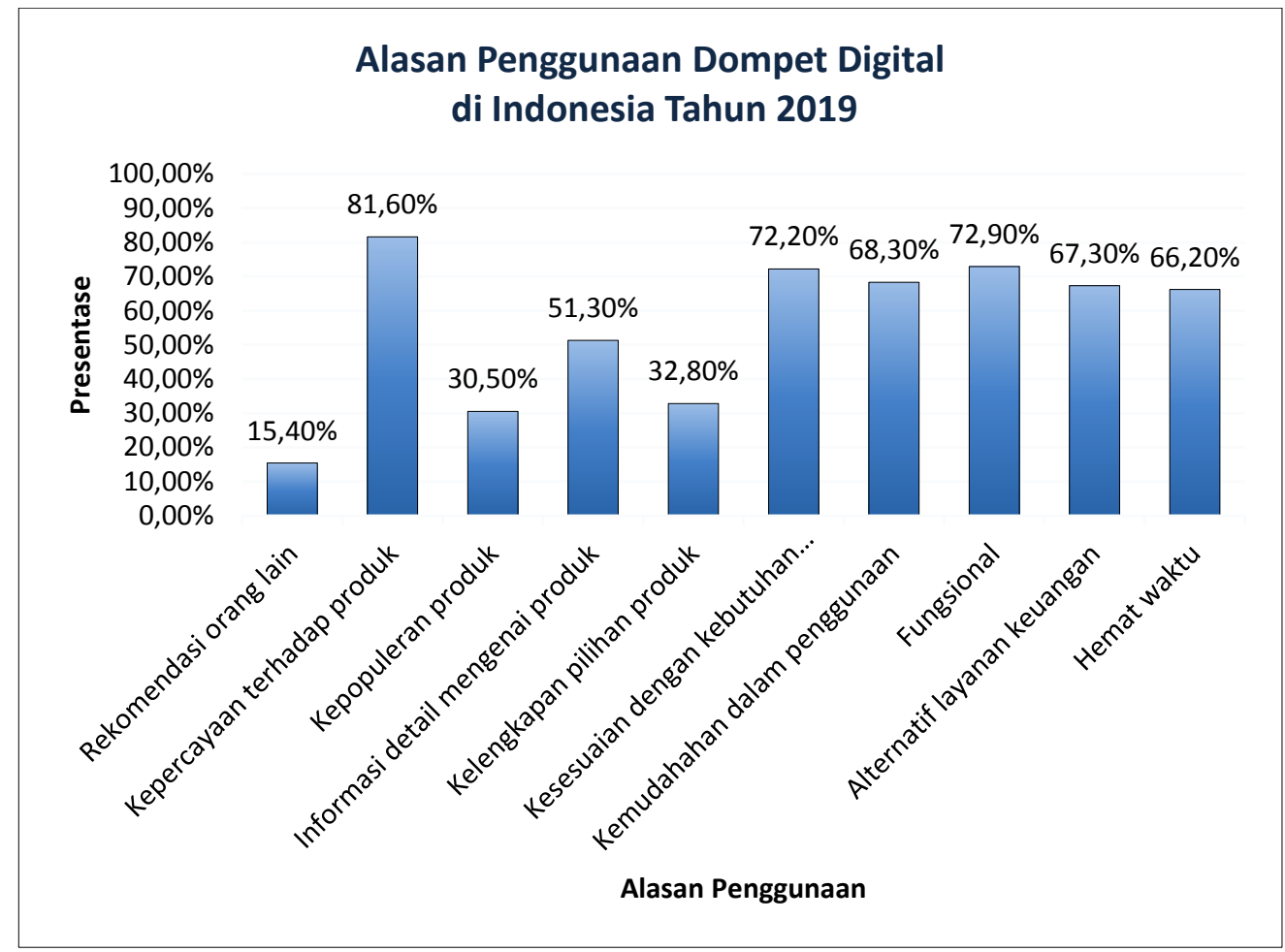

Sumber: Dailysocial Fintech Report (Eka, 2019) 
Grafik pada Gambar 2 menunjukkan bahwa alasan responden memilih menggunakan layanan dompet digital karena faktor kepercayaan terhadap produk $(81,60 \%)$, berdasarkan fungsi atau manfaat $(72,90 \%)$, sesuai dengan kebutuhan $(72,20 \%)$, dan kemudahan dalam penggunaan $(68,30 \%)$. Oleh karena itu, manfaat dan kemudahan dalam menggunakan layanan dompet digital seperti Go-Pay mempunyai peranan yang penting dalam meningkatkan minat pengguna.

Keyakinan terhadap diri sendiri (self-efficacy) menjadi persepsi yang harus dimiliki oleh individual terkait kesulitan ataupun kemudahan dalam melakukan keyakinan ataupun kemampuan diri sendiri untuk melakukannya (Ajzen, 2002 dalam Jogiyanto, 2007). Pengaruh sosial dan self-efficacy memiliki hubungan positif dan signifikan dengan kepercayaan. Model penelitian yang diusulkan telah dimasukkan melalui uji goodness of fit menunjukkan terkait model tersebut cocok. Pengujian tujuh hipotesis dilakukan dengan menggunakan AMOS 21. Hasilnya menunjukkan bahwa tiga hipotesis didukung kemajuan ilmu sosial, pendidikan serta dalam penelitian humaniora, sementara empat dari mereka tidak didukung. Sebuah ikatan negatif ditemukan pada kepercayaan, risiko yang dialami, serta niat. Tes lain menampilkan bahwa risiko yang dialami serta nilai yang dipersepsikan mempunyai hubungan positif dan signifikan pada niat. Ini didukung oleh tes tambahan yang dilakukan oleh peneliti dengan menggunakan efek kepercayaan pada niat sebagai variabel moderasi. Para peneliti menyimpulkan bahwa kepercayaan dipengaruhi oleh pengaruh sosial dan selfefficacy. Namun, ada sedikit kepercayaan masyarakat tentang penggunaan aplikasi seluler dalam melakukan pembayaran. Ini bisa dikaitkan dengan risiko yang dialami dan yang dialami variabel nilai dapat menciptakan perasaan kepercayaan dan niat untuk menggunakan aplikasi tersebut dalam melakukan pembayaran online (Istiyana \& Triana, 2019).

Semakin tinggi self-efficacy yang dimiliki oleh seseorang, semakin tinggi niat dalam menggunakan teknologi. Hasil tersebut mendukung teori sosial kognitif. Semakin tinggi kepercayaan yang dimiliki seseorang, maka semakin tinggi juga niat dalam menggunakan apa yang dirasakan seseorang dalam menggunakan teknologi. Hasil ini mendukung teori kognitif sosial yang mewakili struktur kognitif yang dikembangkan oleh individu. Semakin tinggi kenikmatan seseorang, semakin tinggi niat untuk menggunakan lebih terasa. Hasil ini mendukung motivasi model atau teori motivasi. Semakin spesifik gaya hidup individu, semakin tinggi niat untuk digunakan terasa oleh seseorang dalam penggunaan teknologi yang dianggap sebagai suatu bentuk gaya hidup yang diekspresikan dalam kegiatan, minat, dan opini. Hasil ini mendukung teori keputusan konsumen. Untuk peningkatan kebijakan penyediaan sistem dan pengembangan, Go-Pay khususnya dan perusahaan sejenis yang menyediakan layanan keuangan serupa umumnya harus lebih memperhatikan perilaku individu sebagai pengguna, sehingga para pengguna ini memiliki niat yang kuat untuk menggunakan transaksi keuangan layanan yang diberikan dalam kegiatan sehari-hari. Faktor self-efficacy dari pengguna yang ditargetkan terhadap nilai pelayanan yang disediakan. Pengguna layanan menggunakan berbagai cara untuk mengevaluasi layanan teknologi yang ditawarkan. Kepercayaan pengguna Go-Pay akan membuat mereka loyal untuk terus menggunakan layanan transaksi keuangan yang disediakan (Jumardi et al., 2018). Hasil penelitian Permana dan Dewi (2020) juga memperlihatkan hadirnya pengaruh positif yang signifikan baik secara parsial antara self-efficacy, dengan regulasi 
pemerintah serta word of mouth (getok tular) terhadap penggunaan Go-Pay.

Penelitian Chandra et al. (2018) menunjukkan bahwa responden percaya pada penggunaan Go-Pay hanya karena nama Go-Pay terkenal dan memiliki reputasi baik, sedangkan risiko lingkungan tidak memengaruhi responden. Persepsi kepercayaan harus diterima karena persepsi reputasi. Namun, kepercayaan umum yang dirasakan tidak berpengaruh dalam mendorong responden untuk selalu menggunakan pembayaran dengan Go-Pay. Faktor-faktor yang membuat Go-Pay diterima di Indonesia adalah faktor kemudahan penggunaan, faktor yang bermanfaat bagi masyarakat Indonesia dan pentingnya faktor mobilitas. Oleh karena itu, orang Indonesia sangat mudah untuk menerima Go-Pay sebagai mobile payment di Indonesia.

Penelitian Situngkir et al., (2020) menunjukkan bahwa berdasarkan konstruk pengujian model, perilaku pelanggan menggunakan layanan $E$ Payment dalam hal ini Go-Pay terbukti secara signifikan dipengaruhi satu variabel independen yaitu manfaat. Berkenaan dengan unsur biaya keuangan, berdasarkan dari hasil peneliti ini, diperoleh tidak berpengaruh signifikan pada layanan Go-Pay yang disediakan oleh Go-Jek. Berkaitan dengan aspek metodologis, diharapkan penelitian ini bisa menjadi pembanding untuk riset selanjutnya. Dengan mencakup lebih banyak variabel independen ataupun sebagai variabel intervening, upaya bisa menghasilkan referensi yang membantu perusahaan atau lembaga membangun jasa layanan E-Payment dalam penyusunan strategi bersaingnya.

Penelitian yang dilakukan oleh Priyono (2017) menganalisis mengenai Go-Pay apakah diterima oleh masyarakat, terkhusus oleh para early adopters of innovation yang dalam penelitian ini diprediksi dengan mahasiswa. Technology acceptance model menjadi model yang digunakan pada penelitian tersebut serta banyak digunakan dalam menganalisis penerimaan inovasi dalam teknologi. Model tersebut dirumuskan oleh Davis (1989) yang kemudian dilakukan modifikasi dengan cara memasukkan variabel-variabel laten relevan dengan konteks penelitian variabel-variabel laten baru, yang digunakan dalam penelitian ini adalah family, risk, dan satisfaction. Ketiga variabel tersebut tidak terdapat dalam technology acceptance model yang asli.

Mcknight et al., (2002) mengatakan bahwa kepercayaan itu penting karena hal itu membantu konsumen dalam mengatasi persepsi ketidakpastian, risiko, serta keterlibatan "perilaku yang berkaitan dengan kepercayaan" melalui vendor berbasis web, misalnya berbagi informasi tentang diri pribadi ataupun melakukan aktivitas pembelian. Ada beberapa penelitian yang telah membuktikan bahwa faktor kepercayaan memengaruhi adopsi penerimaan pembayaran seluler, seperti penelitian Penjelajahan Faktor Kunci tentang Penerimaan Penggunaan Teknologi Mobile Payment di Indonesia yang dilakukan oleh Manaf dan Ariyanti (2017). Upaya Go-Jek terutama Go-Pay harus menjaga kepercayaan pelanggannya karena kepercayaan akan memengaruhi manfaat, membentuk citra merek serta meningkatkan keputusan penggunaan, sesuai dengan yang direkomendasikan pada implikasi manajerial (Ambarwati, 2019).

Penelitian Haidari dan Tileng (2018) berdasarkan hasil analisa data statistik serta deskriptif dengan menggunakan 3 variabel diantaranya dapat disimpulkan bahwa 1) Variabel Trust menunjukkan pengaruh positif secara signifikan terhadap Intention to Use Go-Pay sehingga hipotesis pertama $(\mathrm{H} 1)$ dapat diterima dikarenakan hasil yang didapatkan telah sesuai dengan hipotesis; 2) Variabel Perceived Usefulness memberikan pengaruh positif secara 
signifikan terhadap Intension to Use GoPay sehingga hipotesis kedua dapat diterima (H2) karena hasil yang diperoleh sesuai dengan hipotesis; 3) Variabel Perceived Risk tidak memiliki pengaruh positif serta signifikan terhadap Intention to Use Go-Pay sehingga hipotesis ketiga (H3) ditolak karena didapatkan hasil yang tidak sesuai hipotesis.

Penelitian Indrawati dan Putri (2018) menunjukkan bahwa ada enam variabel yang berpengaruh positif serta signifikan pada niat konsumen dalam menggunakan Go-Pay di Indonesia. Variabel tersebut diurutkan berdasarkan pengaruh tertinggi ke terendah sebagai berikut: kebiasaan konsumen, kepercayaan konsumen, pengaruh aspek sosial, harga penyimpan orientasi, motivasi hedonik, serta kinerja harapan. Tidak ada perbedaan persepsi responden dalam hal usia dan jenis kelamin. Model yang diusulkan dari penelitian tersebut memiliki daya prediksi yang baik untuk memprediksi niat kelanjutan pelanggan menuju adopsi Go-Pay. Oleh karena itu, model yang diusulkan ini dapat diimplementasikan dalam menentukan pemasaran manajemen Go-Pay niat berkelanjutan dalam mengadopsi Go-Pay. Analisis data penelitian Nuriska et al., (2018) tentang faktor yang memengaruhi niat perilaku dalam menggunakan Go-Pay dengan menggunakan model modifikasi dari the Unified Theory of Acceptance and Use of Technology 2 (UTAUT2) menyatakan bahwa kebiasaan, kondisi fasilitas, serta nilai harga mempunyai pengaruh signifikan pada perilaku dan niat konsumen menggunakan Go-Pay sebagai metode pembayaran. Selain itu, harapan kinerja dan usaha, pengaruh sosial, serta motivasi hedonik mempunyai efek yang tidak signifikan pada perilaku konsumen dalam menggunakan Go-Pay sebagai metode pembayaran. Tidak hanya itu, hubungan antara kondisi fasilitas dan ekspetasi upaya dengan niat perilaku dalam menggunakan Go-Pay adalah dimoderatori berdasarkan usia, tetapi tidak berdasarkan jenis kelamin dan pendapatan. Pelanggan yang memiliki habit terhadap Go-Pay akan dapat meningkatkan continuance intention (Tekaqnetha, 2020).

Pada dasarnya, semakin baik nilai pelanggan serta kualitas layanan, semakin baik kepuasan pelanggan di perusahaan PT Go-Jek. Temuan ini konsisten dengan pandangan teoretis peneliti sebelumnya tentang beberapa faktor yang berpengaruh terhadap kepuasan pelanggan, di mana nilai pelanggan variabel serta kualitas pada layanan secara signifikan memengaruhi kepuasan para pelanggan dan pelanggan menghargai hal itu (Iskandar et al., 2017). Hasilnya juga mendukung temuan sebelumnya yang dilakukan Karadeniz dan Gozuyukari (2016), Ikasari et al. (2013), dan Suryatiningsih (2013). Penelitian Latief dan Nur (2019) pun menunjukkan variabel persepsi kegunaan, persepsi kemudahan, kepuasan pelanggan serta sikap konsumen memiliki pengaruh yang signifikan pada minat konsumen dalam sistem pembayaran Go-Pay di aplikasi Go-Jek.

Keberadaan Go-Jek ini telah mengubah pola kebiasaan orang yang tidak mengenal dunia digital. Pengguna dan pengendara telah memahami teknologi aplikasi online. Go-Jek menerima resistensi dari konvensional tetapi, karena masyarakat membutuhkannya maka akses menjadi lebih mudah, pengendara ramah, dan biayanya sangat terjangkau. Go-Jek online telah menjadi pilihan bagi kelompok komunitas digital. Kebutuhan akan pengetahuan tentang internet dan keinginan masyarakat dalam menggunakan layanan transportasi ini telah membuat peluang baru dalam bisnis jasa, mampu meningkatkan nilai paket internet transaksi penjualan dan kebutuhan untuk layanan bidang internet ini juga meningkatkan penjualan smart berbasis telepon Android (Haris et al., 2018). Kampanye Go-Pay Pay Day Food 
and Beverage mempunyai kontribusi besar dalam meningkatkan pemahaman masyarakat terhadap layanan keuangan digital dan peningkatan penjualan. Efek yang ditimbulkan adalah perilaku konsumsi masyarakat yang telah bergeser dari kebutuhan primer ke kebutuhan sekunder, dan cenderung bersikap konsumtif (Simanjuntak \& Tamburian, 2020).

Popularitas pembayaran digital yang digunakan oleh konsumen telah mengubah tinjauan bisnis integratif dan penelitian ekonomi. Perkembangan dan percepatan pembayaran merchant elektronik secara luas dapat membantu negara memajukan akses keuangan dan inklusi keuangan. Namun, faktor-faktor yang menghambat adopsi pembayaran digital harus ditangani. Inklusi keuangan merupakan titik masuk penting untuk pertumbuhan inklusi, Go-Pay dapat membantu Usaha Mikro Kecil Menengah (UMKM) yang sebelumnya dikecualikan dan merupakan bagian dari pasar yang kurang terlayani untuk transisi ke dalam sistem formal. Solusi pembayaran digital memungkinkan konsumen dan pedagang untuk memanfaatkan sosial media untuk melakukan aktivitas pembelian serta penjualan barang dan jasa untuk membuat peluang ekonomi baru (Raharja et al., 2020).

\section{Kesimpulan}

Hasil penelitian ini menyatakan bahwa tingkat kemudahan dan manfaat pada penggunaan layanan Go-Pay sangat berpengaruh pada minat pengguna. Konsumen tidak merasa kesulitan dalam mengoperasikannya sehingga mudah digunakan kapan pun dan di mana pun. Hal tersebut menunjukkan penggunaan layanan Go-Pay menjadi alternatif dan digemari oleh masyarakat karena dinilai lebih efektif dan efisien. Tidak hanya itu, Go-Pay memiliki manfaat yang beragam sehingga memiliki daya tarik dan daya saing yang tinggi dibandingkan kompetitornya. Tidak heran masyarakat banyak memilih untuk menggunakan GoPay dibandingkan dengan layanan transaksi lainnya. Jadi, faktor kepercayaan masyarakat akan kemudahan dan manfaat yang diberikan Go-Pay dapat memengaruhi penggunaan Go-Jek secara signifikan.

\section{Daftar Pustaka}

Ambarwati, D. (2019). Pengaruh Persepsi Manfaat, Persepsi Kemudahan dan Persepsi Kepercayaan terhadap Keputusan Penggunaan Go-Pay pada Mahasiswa STIE AUB Surakarta. Jurnal Bisnis dan Ekonomi, 6(2), 88-103. Diakses dari https://e-journal.stieaub.ac.id/index.php/kelola/article/vi ew/531

Aritonang, Y. A. L., \& Arisman, A. (2017). Pengaruh Persepsi Kemudahan dan Persepsi Manfaat terhadap Minat Menggunakan EMoney. Jurnal Akuntansi STIE Multi Data Palembang, 2(1), 1-17. Diakses

dari https://core.ac.uk/download/pdf/153 523739.pdf

Bank Indonesia. (2020). Financial Technology. Diakses dari https://www.bi.go.id/id/edukasiperlindungan-

konsumen/edukasi/produk-dan-jasasp/fintech/Pages/default.aspx

Chandra, Y. U., Kristin, D. M., Suhartono, J., Sutarto, F. S., \& Sung, M. (2018). Analysis of Determinant Factors of User Acceptance of Mobile Payment System in Indonesia (a case study of go-pay mobile payment). Paper presented on International Conference on Information Management and Technology (ICIMTech) in Jakarta 3-5 September 2018. Diakses dari https://ieeexplore.ieee.org/documen t/8528182/keywords\#keywords 
Danuarta, G. L. N., \& Darma, G. S. (2019). Determinants of Using GoPay and its Impact on Net Benefits. International Journal of Innovative Science and Research Technology, 4(11), 173-182. Diakses dari https://ijisrt.com/determinants-ofusing-gopay-and-its-impact-on-netbenefits

Davis, F. D. (1989). Perceived Usefulness, Perceived Ease of Use, and User Acceptance of Information Technology. MIS Quarterly, 13(3), 319-340. doi: https://doi.org/10.2307/249008

Eka, Randy. (2019, November 26). Fintech Report 2019: Moving Towards a New Era in Indonesia's Financial Industry. Diakses dari https://dailysocial.id/research/indon esia-fintech-report-2019\#

Ferdiana, A. M. K., \& Darma, G. S. (2019). Understanding Fintech Through Go-Pay, International Journal of Innovative Science and Research Technology, 4(2), 257$260 . \quad$ Diakses dari https://ijisrt.com/understandingfintech-through-go-pay

Haidari, M. B., \& Tileng, K. G. (2018). Analisa Faktor-Faktor Berpengaruh pada Penggunaan Go-Pay. Jurnal Informatika dan Sistem Informasi (JUISI), 4(1), 10-15. Diakses dari https://journal.uc.ac.id/index.php/J $\underline{\mathrm{UISI} / \text { article/view/690 }}$

Haris, A., Kholil, S., \& Zulkarnain, I. (2018). The Islamic Perspective of Marketing Communication in online Business Advertisement: A Case Study in Go-Jek Online Transport Sales Service. International Journal of Research and Review, 5(12), 270$276 . \quad$ Diakses dari https://www.ijrrjournal.com/IJRR Vol.5_Issue.12_Dec2018/IJRR0041 .pdf
Ikasari, A. U., Suryoko, S., \& Nurseto, S. (2013). Pengaruh Nilai Pelanggan dan Kualitas Pelayanan terhadap Kepuasan Pelanggan (Studi Kasus pada Penumpang KA Kaligung Mas di Stasiun Poncol Semarang). Jurnal Ilmu Administrasi Bisnis, 2(2), 1-8. Diakses dari https://ejournal3.undip.ac.id/index.p hp/jiab/article/view/2178/2198

Indrawati., \& Putri, D. A. (2018). Analyzing Factors Influencing Continuance Intention of E-Payment Adoption Using Modified UTAUT 2 Model. Paper presented on 6th International Conference on Information and Communication Technology (ICoICT) in Bandung 35 May 2018. Diakses dari https://ieeexplore.ieee.org/documen $\underline{\mathrm{t} / 8835196}$

Iskandar, H., Wibowo, I., \& Subagja, I. K. (2017). Effect of Customer Value and Quality of Service on Customer Satisfaction (Case study on Consumers GO-JEK, Jakarta Indonesia). International Journal of Advanced Scientific Research, 2(5), 28-39. Diakses dari http://www.allscientificjournal.com/ archives/2017/vol2/issue5/2-5-15

Istiyana, A. N., \& Triana, D. (2019). The Effect of Trust to Users to Use GoPay and Grab-Pay as Payment Method. Paper presented on International Conference of Ethics on Business, Economics, and Social Science (ICEBESS 2018) in 2018. doi: https://doi.org/10.2991/icebess$\underline{18.2019 .2}$

Joan, L., \& Sitinjak, T. (2019). Pengaruh Persepsi Kebermanfaatan dan Persepsi Kemudahan Penggunaan Terhadap Minat Penggunaan Layanan Pembayaran Digital GoPay. Jurnal Manajemen, 8(2), 27$39 . \quad$ Diakses dari https://jurnal.kwikkiangie.ac.id/inde x.php/JM/article/view/596 
Jogiyanto. (2007). Sistem Informasi Keprilakuan. Yogyakarta: Andi.

Jumardi., Pontoh, G. T., \& Nirwana (2018). Analysis of Factors Influencing Intention to Use Financial Transaction Services on Go-Pay. International Journal of Innovative Science and Research Technology (IJISRT), 3(11), 701$707 . \quad$ Diakses dari https://ijisrt.com/analysis-offactors-influencing-intention-touse-financial-transaction-serviceson-go-pay

Karadeniz, M., \& Gozuyukari, M. (2016). The Effect of Perceived Service Quality in Banking Sector on Customer Satisfaction. Journal of Administrative Sciences, 14(28), 533-552. Diakses dari http://acikerisim.lib.comu.edu.tr:80 80/xmlui/bitstream/handle/COMU/ 1626/Mustafa_Karadeniz_Makale.p df? sequence $=1$ \&isAllowed $=y$

Kesumastuti, T. M. (2020). The Process of Adoption Interest in Using Digital Wallet in Central Jakarta (Case Study on Go-Pay Users). International Journal of Multicultural and Multireligious Understanding, 7(2), 277-286. Diakses dari https://ijmmu.com/index.php/ijmmu /article/view/1463

Latief, F., \& Nur, Y. (2019). Technology Acceptance Model (TAM) terhadap Minat Konsumen Sistem Pembayaran Gopay pada Layanan Gojek. Bongaya Journal for Research in Management, 2(2), 111. Diakses dari https://ojs.stiembongaya.ac.id/index.php/BJRM/arti cle/view/201/146

Liu, J., Kauffman, R. J., \& Ma, D. (2015). Competition, Cooperation and Regulation: Understanding The Volution of The Mobile Payments Technology Ecosystem. Electronic
Commerce Research and Applications, 14(5), 372- 391. doi: https://doi.org/10.1016/j.elerap.201 $\underline{5.03 .003}$

Manaf, N. R., \& Ariyanti, M. (2017). Exploring Key Factors On Technology Acceptance of Mobile Payment Users in Indonesia Using Modified Unified Theory of Acceptance and Use of Technology (UTAUT) Model Use Case: ABC Easy Tap. International Journal of Management and Applied Science, 3(1), 40-44. Diakses dari http://www.iraj.in/journal/journal_fi le/journal_pdf/14-340148921185840-44.pdf

Mcknight, D. H., Choudhury, V., \& Kacmar, C. (2002). Developing and Validating Trust Measures for eCommerce: An Integrative Typology. Information Systems Research, 13(2), 334-359. Diakses dari

https://msu.edu/ mcknig26/Measur es.pdf

Nuriska, A., Asakdiyah, S., Setyawan, R. R., Program, M. M., Dahlan, U. A., \& Malang, U. M. (2018). Factors Affecting Behavioral Intention in Using Go-Pay with The Modified Unified Theory of Acceptance and Use of Technology 2 Model (UTAUT2). Muhammadiyah International Journal of Economics and Business, 1(2), 107-114. doi: https://doi.org/https://doi.org/10.23 917/mijeb.v1i2.9366

Permana, G. P. L., \& Dewi, N. L. P. P. (2020). Analisis Faktor Penggunaan Layanan Go-Pay oleh Generasi Millenial di Kota Denpasar. Widya Akuntansi Dan Keuangan, 2(1), 3251.

doi: https://doi.org/10.32795/widyaakun $\underline{\text { tansi.v2i1.539 }}$ 
Priyono, A. (2017). Analisis Pengaruh Trust dan Risk dalam Penerimaan Teknologi Dompet Elektronik GoPay. Jurnal Siasat Bisnis, 21(1), 88106.

doi: https://doi.org/10.20885/jsb.vol21.is $\underline{\text { s1.art6 }}$

Raharja, S. J., Sutarjo, Muhyi, H. A., \& Hewawaty, T. (2020). Digital Payment as an Enabler for Business Opportunities: A Go-Pay Case Study. Review of Integrative Business and Economics Research, 9(1), 319-329. Diakses dari https://search.proquest.com/openvie w/e702fdc6159a7fcc0342beeb0ce8 cb73/1?pqorigsite $=$ gscholar $\& \mathrm{cbl}=2032316$

Simanjuntak, C. T., \& Tamburian, H. H. D. (2020). Pengaruh Kampanye GoPay Day Food and Beverage terhadap Perilaku Konsumtif Pengguna (Survei Pada Karyawan P . T Pionir Maxima Mutu Indonesia). Prologia, 4(1), 113-120. doi: https://doi.org/10.24912/pr.v4i1.644 $\underline{6}$

Situngkir, T. L., Hurriyati, R., \& Sultan, M. A. (2020). Faktor-Faktor yang Mempengaruhi Pengguna Gojek menggunakan Gopay (Factors that Influence Gojek Users to utilize Gopay). Jurnal Samudra Ekonomi dan Bisnis, 11(1), 111-121. doi: https://doi.org/10.33059/jseb.v11i1. $\underline{1998}$

Suryatiningsih, S. (2013). Analisis Pengaruh Kualitas Pelayanan dan
Nilai Pelanggan terhadap Kepuasan Nasabah (Studi Kasus pada Bank Sumsel Babel). Tugas Akhir. Universitas Terbuka Jakarta.

Susilo, A. Z., Prabowo, M. I., Taman, A., Pustikaningsih, A., Susilo, A. Z., Ahmad, M. I., Taman, A., Pustikaningsih, A., \& Samlawi, A. (2019). A Comparative Study of Factors Affecting User Acceptance of Go-Pay and OVO As a Feature of Fintech Application. Procedia Computer Science, 161, 876-884. doi:

https://doi.org/10.1016/j.procs.2019 .11 .195

Tekaqnetha, G. (2020). Faktor yang Mempengaruhi Continuance Intention GO-PAY di Jakarta. Jurnal Manajerial Dan Kewirausahaan, 2(1), 173-181. Diakses dari https://journal.untar.ac.id/index.php /JMDK/article/view/7457

Vivin, D. (2019). Riset Data Aplikasi EWallet di Indonesia. Jakarta: Iprici Group.

Wulandari, C., Syah, L. Y., \& Abdillah, L. A. (2016). Analisa Tingkat Kepuasan Layanan TI (Studi Kasus Pada Aplikasi Gojek). Paper presented on Seminar Nasional Teknologi Informasi dan Komunikasi ke-8 (SEMNASTIK 2016) in Palembang 20 Agustus $2016 . \quad$ Diakses dari http://eprints.binadarma.ac.id/3230/ 